\title{
Comparative proteomic analysis of metabolically labelled proteins from Plasmodium falciparum isolates with different adhesion properties \\ Yang Wu and Alister Craig*
}

\author{
Address: Liverpool School of Tropical Medicine, Pembroke Place, Liverpool L3 5QA, UK \\ Email: Yang Wu - ywu@liv.ac.uk; Alister Craig* - agcraig@liv.ac.uk \\ * Corresponding author
}

Published: 03 August 2006

Malaria Journal 2006, 5:67 doi:10.1186/1475-2875-5-67

This article is available from: http://www.malariajournal.com/content/5/I/67

(c) 2006 Wu and Craig; licensee BioMed Central Ltd.

This is an Open Access article distributed under the terms of the Creative Commons Attribution License (http://creativecommons.org/licenses/by/2.0), which permits unrestricted use, distribution, and reproduction in any medium, provided the original work is properly cited.

\begin{abstract}
The virulence of Plasmodium falciparum relates in part to the cytoadhesion characteristics of parasitized erythrocytes but the molecular basis of the different qualitative and quantitative binding phenotypes is incompletely understood. This paucity of information is due partly to the difficulty in working with membrane proteins, the variant nature of these surface antigens and their relatively low abundance. To address this two-dimensional (2D) protein profiles of closely related, but phenotypically different laboratory strains of $P$. falciparum have been characterized using proteomic approaches. Since the mature erythrocyte has no nucleus and no protein synthesis capability, metabolic labelling of proteins was used to selectively identify parasite proteins and increase detection sensitivity.

A small number of changes (less than 10) were observed between four different $P$. falciparum laboratory strains with distinctive cytoadherence properties using metabolic labelling, with more parasite protein changes found in trophozoite iRBCs than ring stage. The combination of metabolic labelling and autoradiography can therefore be used to identify parasite protein differences, including quantitative ones, and in some cases to obtain protein identifications by mass spectrometry. The results support the suggestion that the membrane protein profile may be related to cytoadherent properties of the iRBCs. Most changes between parasite variants were differences in iso-electric point indicating differential protein modification rather than the presence or absence of a specific peptide.
\end{abstract}

\section{Background}

The virulence of the human malaria parasite Plasmodium falciparum is believed to relate in part to adhesion of parasitized erythrocytes to postcapillary venular endothelium and other uninfected blood cells. At the molecular level, surface antigens from infected erythrocytes interact with several host receptors such as CD36 [1-3], Intercellular adhesion molecule-1 (ICAM-1) (CD54) [4], throm- bospondin [5], E-selectin (CD62E), vascular cell adhesion molecule VCAM-1 (CD106) [6], P-selectin (CD62P) [7], $\alpha_{v} \beta_{3}$-integrin [8], platelet endothelial cell adhesion molecule-1 [PECAM-1 (CD31)] [9], Chondroitin sulfate A (CSA) [10], Complement receptor-1 (CR-1)),(CD35) [11], Heparan sulphate (HS)-like Glycosaminoglycan (GAG) [12], ABO blood group antigens [13] resulting in the rosetting, agglutination [14] and cytoadherence of 
iRBC. A parasite-derived adhesion molecule that mediates these interactions has been identified as $P$. falciparum erythrocyte membrane protein 1 (PfEMP1), which is encoded by the var multigene family [15-17]. There are about 60 var genes per parasite genome [18] that switch on expression in a mutually exclusive manner and contain copies of motifs that bind to diverse host receptors. Direct association of specific adhesive phenotype with disease has not been easy to demonstrate, except for pregnancyassociated malaria, in which the ability of iRBC to bind to placental receptors (such as CSA) is closely related to poor maternal and neonatal outcome [19]. A number of other parasite proteins associated with the erythrocyte membrane and exported on the surface of parasitized erythrocytes have been reported, including, Rifin, Stevor, ring surface protein (RSP) 1/2, (for a review see [20]) and, more recently, Surfins [21]. These proteins form part of a group of $P$. falciparum proteins that contain signals for export from the parasitophorous vacuole [22,23]. Further bioinformatic analysis has proposed over 200 proteins that contain these signals and this behaviour appears to have been adopted much more extensively in $P$. falciparum than in other Plasmodium species [24], perhaps in part due to its requirement to undergo antigenic variation and cytoadherence.

There is a correlation between parasite clones of different antigenic type and cytoadherence $[25,26]$, rosette formation and pathogenesis, which has led to the studies on the diversity of these properties in $P$. falciparum isolates by testing binding to purified host proteins or cell lines. The parental $P$. falciparum line IT4/25/5 was originally selected by binding to ICAM-1, C32 amelanotic melanoma cells and Human umbilical vein endothelial cells (HUVEC), followed by sub-cloning to produce ItG [27], A4 and C24 [25]. These parasite clones have distinctive cytoadherence properties $[28,29]$. ItG is a high avidity ICAM-1 and CD36 binder, A4 has high avidity for CD36 and lower avidity to ICAM-1, and C24 binds strongly to CD36 with high avidity but not to ICAM-1. An unrelated parasite line, 3D7, is a low binding line, which has low avidity for CD36 and does not bind ICAM-1. However, the molecular basis underpinning these distinctive binding phenotypes and the molecules involved, other than PfEMP1, are poorly understood. Therefore, the very high resolving power of 2D autoradiography of metabolically-labelled proteins has been used to investigate these genotypically related clones that exhibit distinct adhesion phenotypes to identify the repertoire of molecules involved.

$P$. falciparum infection is a sophisticated system including adaptation and interaction of the human erythrocyte and the parasite. At the early ring stage, very few parasite proteins have been synthesized and so the contribution of the ring-stage parasite to the overall protein biomass of the infected erythrocyte is much less than the human proteins, making it hard to distinguish differences between parasite strain protein profiles at this stage. However, the mature human erythrocyte has no nucleus, no protein synthesis capability and no protein trafficking machinery. Metabolic labelling of proteins of $P$. falciparum can easily indicate parasite protein changes. Moreover, metabolic labelling is a more sensitive method for protein detection; the detection limit for silver stained protein spot is $200 \mathrm{ng}$ while the limit for autoradiography of radioisotope labelled protein is $1 \mathrm{ng}$. In this study, metabolic incorporation was used to label cultured isolates of $P$. falciparum with [ ${ }^{35}$ S] methionine combined with biochemical enrichment of the infected erythrocyte membrane compartment. The objectives of this study were to use proteomic approaches to obtain a snapshot of $P$. falciparum infection at the protein level in the iRBC membrane and free parasite fractions, compare specific parasite strains to find molecules differentially expressed in parasite isolates with defined adhesion properties and to identify the proteins of interest using MALDI-TOF.

\section{Materials and methods Parasite culture}

The P. falciparum isolates used in this study were: ItG [27] A4, C24 [25] and 3D7 [30,31]. Parasites were cultured in vitro in group $\mathrm{O}^{+}$human erythrocytes using previously described conditions [32]. Briefly, parasites were cultured in RPMI1640 medium (supplemented with $37.5 \mathrm{mM}$ HEPES, $7 \mathrm{mM}$ D-glucose, $6 \mathrm{mM} \mathrm{NaOH}, 25 \mu \mathrm{g} \mathrm{ml}-1$ gentamicin sulphate, $2 \mathrm{mM}$ L-glutamine and $10 \%$ human serum) at a $\mathrm{pH}$ of 7.2 in a gas mixture of $96 \%$ nitrogen, $3 \%$ carbon dioxide and 1\% oxygen. To minimize the effect of antigenic switching in culture, a batch of stabilates was prepared from post-selection cultures and used for no more than three weeks. To obtain specific life cycle stages of $P$. falciparum, 5\% sorbitol treatment or Plasmagel flottation was used. For this study, the trophozoites were obtained 20-24 hours after invasion and ring stages were obtained 6-10 hours after invasion.

\section{Two-dimensional electrophoresis}

Synchronized parasite culture was incubated in $0.05 \%$ saponin for 10 minutes ( $\mathrm{min}$ ) in PBS on ice to lyse erythrocytes. The lysate was collected by centrifugation at $10000 \times \mathrm{g}$ for $5 \mathrm{~min}$ and washed three times with $10 \mathrm{mM}$ Tris-HCl pH7.4 with $1 \times$ protease inhibitor Cocktail (Roche) until RBC ghosts were colourless. The lysate was divided into two fractions; red cell ghosts were collected from surface lysate and free parasite pellet from the bottom of the lysate. The two fractions were washed twice more with Tris-HCl buffer, pelleted and solubilized in 2D rehydration buffer [8 M urea, $2 \mathrm{M}$ thiourea, 2\% CHAPS, $65 \mathrm{mM}$ dithiothreitol (DTT), and 0.5\% ampholyte pH4-7 or 3-10]. For RBC ghost fraction, $50 \mu$ l chaotropic mem- 
brane extraction reagent 2 (Sigma) $5 \mathrm{M}$ urea, $2 \mathrm{M}$ thiourea, $40 \mathrm{mM}$ Tris base, 2\% CHAPS, 2\% SB3-10 and $25 \mu \mathrm{l} /$ $\mathrm{ml}$ of tributylphosphine (TBP) were added to help solubilize the erythrocyte membranes, and then solubilized in $2 \mathrm{D}$ rehydration buffer. Then the sample was vortexed, sonicated on ice 10 times for five seconds followed by centrifugation at $15000 \times \mathrm{g}$ for $10 \mathrm{~min}$ and the supernatant was subjected to 2D electrophoresis. The iso-electric focusing (IEF) was performed with pre-cast Amersham immobiline Drystrip gels using IPGphor IEF Unit (Amersham) initially for $10 \mathrm{~h}$ for $30 \mathrm{v}$, followed by $40 \mathrm{~min}$ at $200 \mathrm{v}, 1 \mathrm{~h}$ at $500 \mathrm{v}, 4 \mathrm{~h}$ at $2000 \mathrm{v}$ and terminated with $8 \mathrm{~h}$ at $8000 \mathrm{v}$; a total of $80,000 \mathrm{vh}$. The focused strips were equilibrated in $10 \mathrm{ml}$ equilibration solution $(50 \mathrm{mM}$ Tris$\mathrm{HCl}, \mathrm{pH} 6.8,6 \mathrm{M}$ urea, 30\% glycerol, 2\% Sodium dodecyl sulphate (SDS)) with reducing agent of $1 \%$ DTT for 10 min, followed by $10 \mathrm{ml}$ equilibration solution with $4.5 \%$ iodoacetamide for another $10 \mathrm{~min}$. The strips were then washed twice briefly with $1 \times$ SDS gel running buffer and loaded on $10 \%$ or $12.5 \%$ SDS-polyacrylamide gel electrophoresis (PAGE) gels for second dimension separation. The gels were usually run overnight using a Laemmli buffer system [33]. Gels were stained either with Coomassie brilliant blue or silver nitrate according to a previously published protocol [34].

\section{Metabolic labelling and fluorography}

Parasites grown to specific developmental stages were adjusted to $10 \%$ parasitaemia and cells were washed with serum-free RPMI 1640 medium without methionine three times. In vitro metabolic labelling was carried out in methionine-free RPMI medium by the addition of $50 \mu \mathrm{Ci} /$ $\mathrm{ml}\left[{ }^{35} \mathrm{~S}\right]$ methionine for four hours under standard culture conditions. The reaction was stopped by removing the radioisotope by centrifugation and washing. To extract proteins from the radio-labelled culture, saponin was added to a final concentration of $0.15 \%$ at $4{ }^{\circ} \mathrm{C}$ for $10 \mathrm{~min}$ to lyse the erythrocytes. Following centrifugation at $15,000 \mathrm{~g}$ at $4{ }^{\circ} \mathrm{C}$ for $10 \mathrm{~min}$., the iRBC ghost and free-parasite pellet were collected separately, washed three times using RPMI 1640 without serum and two times of $10 \mathrm{mM}$ Tris-HCl pH7.4 until colourless. The samples were pelleted and subjected to 2D-electrophoresis. After electrophoresis, the gel was fixed and stained with Coomassie Blue, immersed in Amplify (Amersham) for $30 \mathrm{~min}$ and dried for fluorography. Following staining with Coomassie Blue or silver nitrate, 2D gel images were acquired using a Powerscan scanner and differential analysis was performed using 2D Evolution software (Nonlinear, Newcastle, UK).

\section{Spot picking and in gel digestion}

SDS-PAGE gels were Coomassie Brilliant Blue-stained and protein spots of interest either from the membrane enriched fractions (Figure 7) or free parasite fraction (Fig- ure 8) were excised and put into Eppendorf Ultra Pure 1.5 $\mathrm{ml}$ centrifuge tube (to avoid contamination and false results from lower-grade plastics). The bands were then cut into $1 \mathrm{~mm}^{3}$ cubes and rinsed twice in $200 \mu \mathrm{l}$ MilliQ water for 15 minutes. The gel slices were dehydrated by the addition of $100 \mu \mathrm{l}$ of $50 \%(\mathrm{v} / \mathrm{v})$ acetonitrile/water and incubated at room temperature for 10 minutes, and the dehydrants removed. $100 \mu \mathrm{l}$ of ammonium bicarbonate $(50 \mathrm{mM})$ was then added to each sample and incubated again at room temperature for 10 minutes. These last two steps were repeated. After removal of the ammonium bicarbonate the gel fragments were incubated in $10 \mu \mathrm{l}$ of sequence grade trypsin (Promega) $(10 \mu \mathrm{g} / \mathrm{ml}$ in $50 \mathrm{mM}$ ammonium bicarbonate) for 18 hours at $37^{\circ} \mathrm{C}$ and then centrifuged. The supernatant was retained and the gel pellet treated with $20 \mu \mathrm{l}$ of $70 \%$ acetonitrile (v/v in water) for 10 minutes at room temperature. The supernatant from this step was then removed and pooled with the previous supernatant. The combined supernatant was dried in a rotational vacuum concentrator (RVC2-18), resuspended in $15 \mu \mathrm{l}$ water, dried again and resuspended in $12 \mu \mathrm{l}$ of $10 \%$ acetonitrile and $0.1 \%$ formic acid (in water).

\section{MALDI-TOF mass spectrometry}

Samples were loaded in a sandwich manner by adding and immediately removing $0.5 \mu \mathrm{l}$ matrix $[10 \mathrm{mg}$ cyano-4hydroxycin-namic acid (Sigma) in $1 \mathrm{ml} \mathrm{50 \%} \mathrm{acetonitrile}$ and $0.05 \%$ trifluoroacetic acid (TFA)] onto a stainless steel target. Then $0.5 \mu \mathrm{l}$ of prepared sample was spotted directly onto the target and an equal volume of matrix was added. High-resolution spectra were obtained using a Axima-CFR plus MALDI ToF instrument (Kratos Analytical, Manchester, UK) in reflectron mode. External calibration was performed using a mixed 3 point standards (Angiotensin II, 1046.54, ACTH fragment 18-39, 2465.19, Bradykinin gragment 1-7, 757.39, Sigma) adjacent to the samples. Acquisition and data processing are controlled by Launchpad software (Kratos Analytical, Manchester, UK).

\section{Database searching}

Protein identification was performed by sending trypsin digested peptide masses to three databases (NCBI, MSDA and Swissprot) separately using the MASCOT Peptide Mass Fingerprinting program [35]. All the modifications listed in the searching programme were considered individually as a parameter for the search. The monoisotopic masses were used and the mass tolerance was set to $0.5 \mathrm{Da}$.

\section{Results and discussion}

Red blood cells (RBCs) are relatively simple cells that lack internal organelles and are enclosed by a plasma membrane. For iRBCs, the main parasite structure resides within a vacuolar membrane but progressively interacts with host proteins such as ankyrin and spectrin $[36,37]$ in 
the RBC membrane by inserting parasite-derived proteins, forming knob-like structures and changing the rigidity of the infected cell [38]. In order to analyze parasite protein expression and distinguish free parasite protein from RBC membrane proteins, iRBCs were treated with hypotonic ionic buffer, to rupture and release their internal haemoglobin and free the parasite, leaving membrane ghosts that can be collected from the surface of the free-parasite pellet after centrifugation. This ghost fraction contains mainly erythrocyte membrane, as well as proteins from parasite source that are still associated with the erythro- cyte membrane even after extensive washing. The free-parasite fraction more precisely reflects the expression of parasite proteins in general. When the $2 \mathrm{D}$ gel of RBC ghost fraction was stained with Coomassie Blue (Figure 1), A4 iRBC looked almost identical to 3D7 iRBC, with the only visible change being a 200 kilo Dalton (kDa) protein with different iso-electric point (PI), which was more acidic in A4 than in 3D7. This protein was identified as ankyrin by MALDI-TOF. As neither Coomassie Blue nor silver stain methods were able to highlight differential protein patterns between 3D7 and A4 isolates (Figure 1),
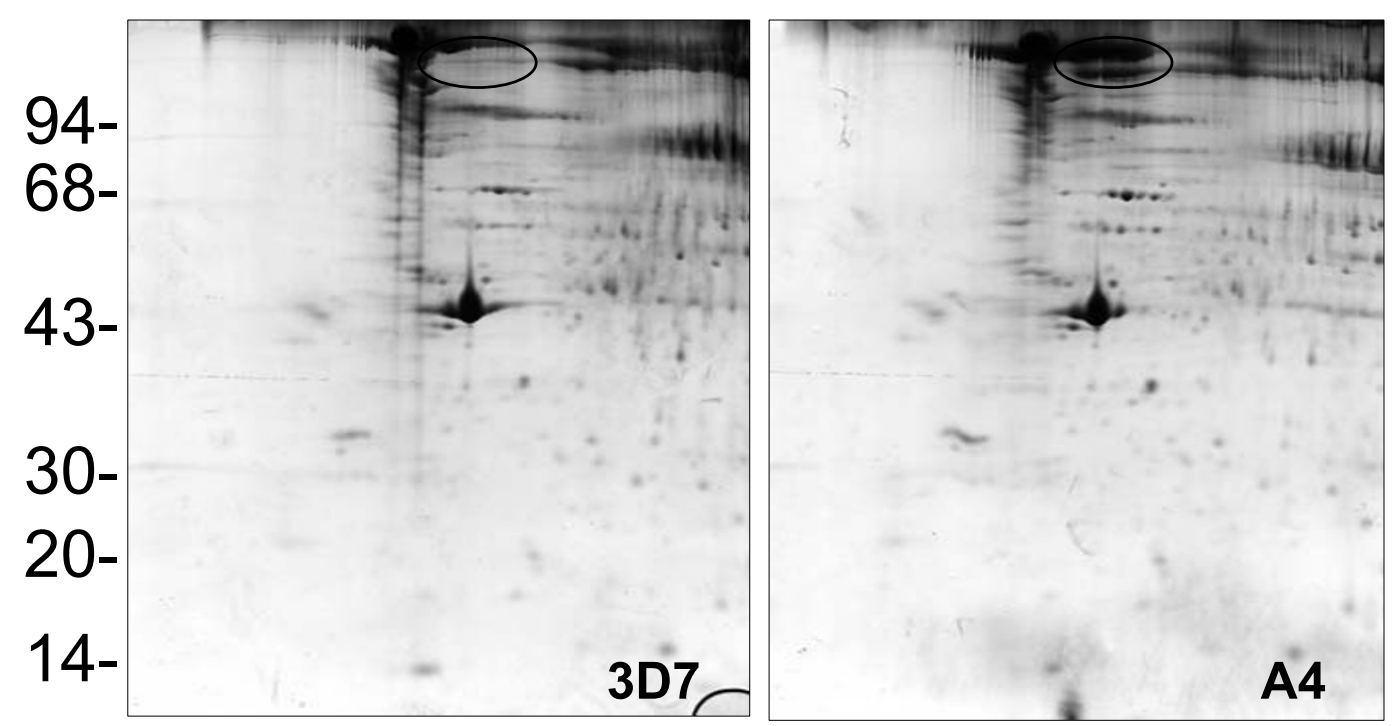

\section{Blue}
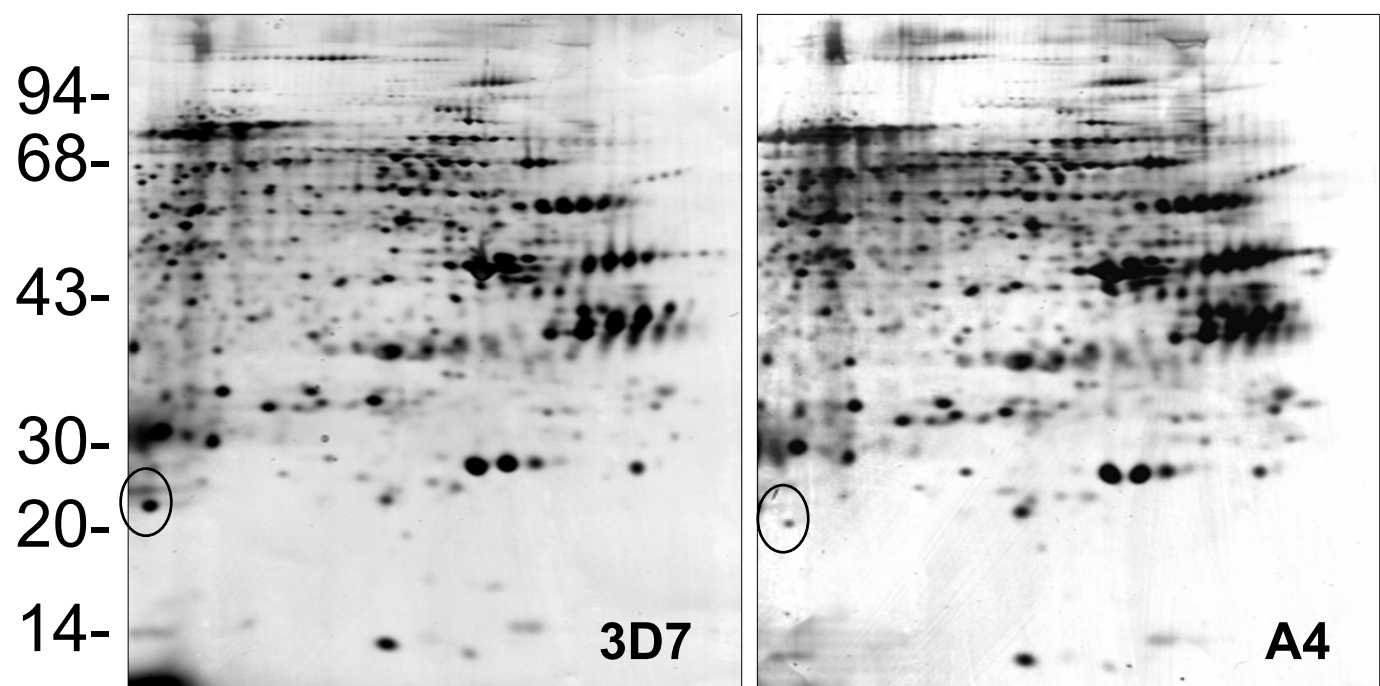

\section{Silver}

\section{Figure I}

2D electrophoresis profile of Coomassie Blue (upper) and silver (lower) stained iRBC ghosts from 3D7 (left) and A4 (right). The first dimension was run on $\mathrm{pH} 4-7$ IEF strips followed by 12.5\% SDS-PAGE. The two major changes in the protein profiles are ringed (see text for details). High quality tif files showing the original 2D gels are available for 3D7 iRBC ghosts stained with Coomassie Blue (Additional file I) and Silver (Additional file 2), and for A4 iRBC ghosts stained with Coomassie Blue (Additional file 3) and silver (Additional file 4). 
[35S] methionine labelling in vivo was used so that only parasite proteins would be labelled and detected, as mature erythrocytes have no protein synthesis. As expected, the uninfected erythrocyte gel (data not shown) did not show any protein spots, while the iRBC ghost fraction contained a number of parasite proteins (Figures 2 and 3), with more parasite proteins seen in trophozoite than ring stage iRBC, suggesting that a number of parasite proteins have a tight association with the RBC membrane. The free-parasite fractions were also analysed after [ $\left.{ }^{35} \mathrm{~S}\right]$ methionine labelling; the autoradiographs of the free parasite preparations of ring and trophozoite stages from three different parasite lines are shown in Figures 4 and 5. Consistent with the genotype identity of A4, C24 and ItG, their 2D protein maps show very similar protein profiles, with the small number of variable proteins indicated by circles on the gels. Nevertheless, since A4, C24 and ItG were selected in vitro for different adhesive phenotypes and are known to express variant PfEMP1 proteins, clonespecific protein expression profiles would be expected, particularly in proteins associated with the membrane or surface fraction. However, the autoradiographs of both iRBC erythrocyte membrane ghost and free-parasite fractions showed only very subtle changes. Using the 2D Evolution software, a number of changes were identified with over three-fold difference in signal intensity (see marked spots in Figures 2 to 5). Interestingly, most changes were between $\mathrm{C} 24$ and either $\mathrm{A} 4$ or ItG profiles, suggesting that A4 and ItG were more similar, consistent with their ability to bind ICAM-1. Another P. falciparum strain, 3D7, is a poorly cytoadherent line but the complete sequence of its genome makes it the best candidate for functional genomics and proteomics study. Therefore, 2D autoradiographs of parasites were compared from the IT4/25/5 lineage with 3D7. As shown in Figure 1, comparison of 3D7 with A4 did not reveal many changes, reflecting the predominance of host proteins. However, autoradiography revealed several distinctions between the protein profiles of the 3D7 trophozoite stage iRBC and either A4 or ItG (Figure 6A), while iRBC of A4 and ItG, as before, displayed almost identical maps. In the enlarged image of the boxed area of Figure 6A (Figure 6B), examples of protein position changes have been listed. In a limited area around pH4-5, molecular weight 45 to $60 \mathrm{kDa}$, three spots show significant changes from $3 \mathrm{D} 7$ and $\mathrm{A} 4$ or $\mathrm{ItG}$, in all three cases resulting from more basic proteins in the 3D7 sample. This could be due to lower phosphorylation of these proteins in 3D7 than A4 or ItG, however, the role of phosphorylation in $P$. falciparum and its regulation are not known. The higher degree of difference in protein profiles between 3D7 and IT4/25/5-derived strains was also reflected in the comparison of profiles from ring stage
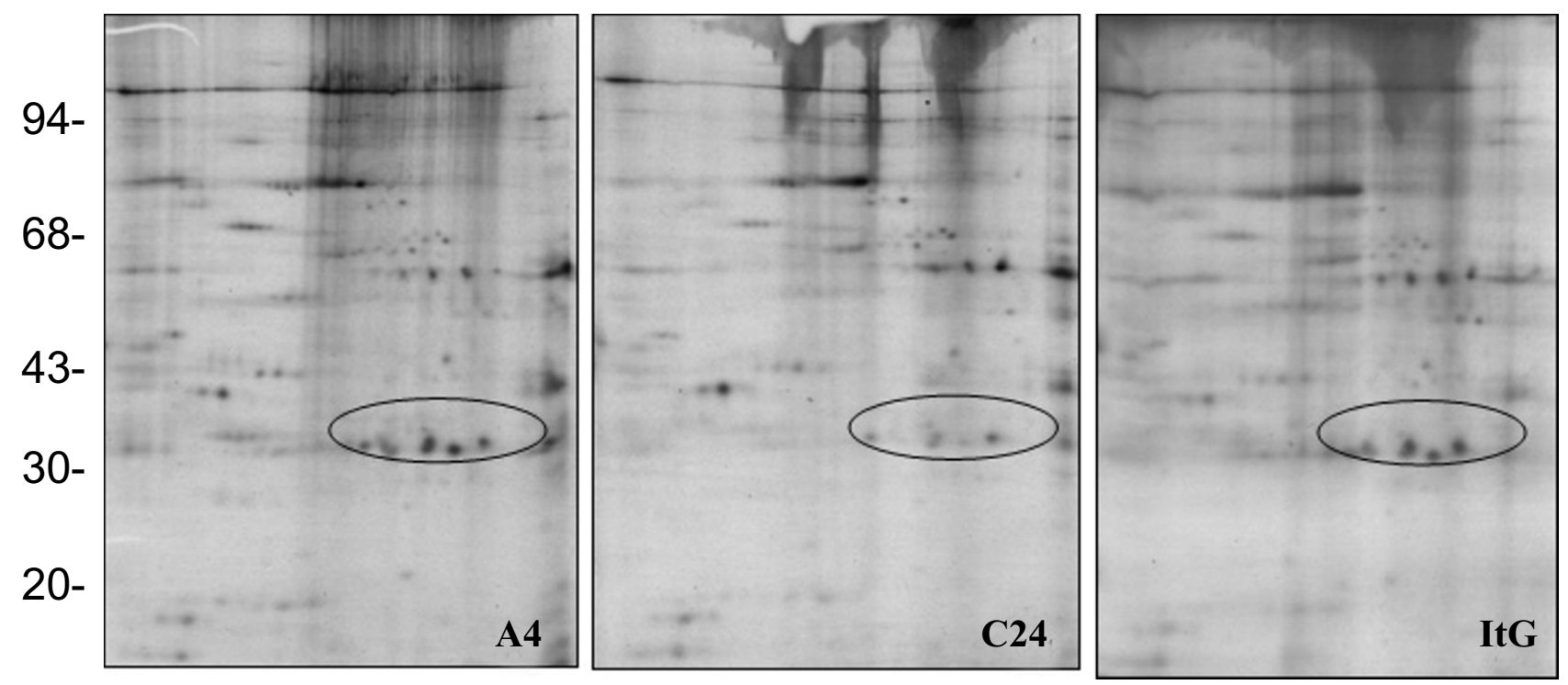

\section{Figure 2}

Autoradiograph of proteins from ring stage iRBC ghosts from A4, C24 and ItG. At 6 hours after invasion, parasites were metabolic labelled by $50 \mu \mathrm{Ci} / \mathrm{ml}\left[{ }^{35} \mathrm{~S}\right]$ methionine for 4 hours. IRBC ghosts were separated from the free parasite fraction and run on pH 4-7 IEF strips followed by 10\% SDS-PAGE. Gels were stained with Coomassie Blue, dried and exposed to x-ray film. Marked circles show proteins with at least three fold changes in expression compared with C24. High quality tif files showing the original 2D gels are available for A4 (Additional file 5), C24 (Additional file 6) and ItG (Additional file 7) iRBC ghosts from ring stages. 

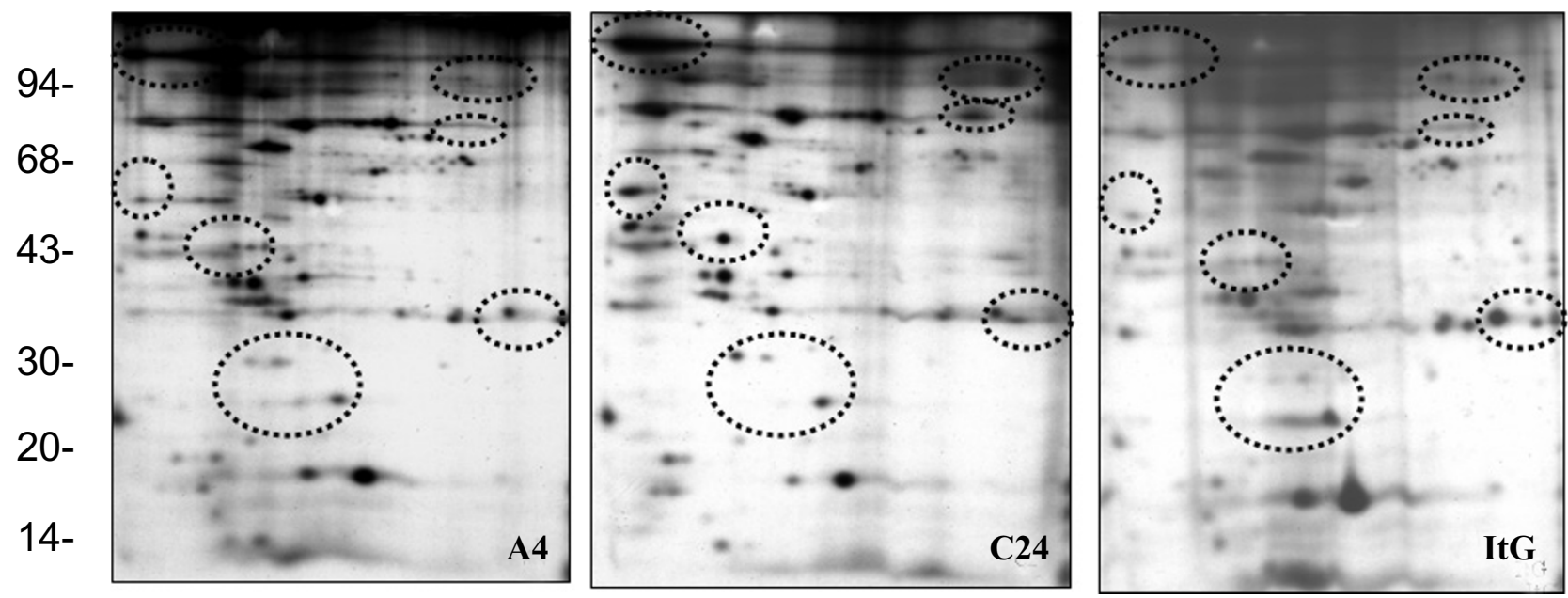

\section{Figure 3}

Autoradiograph of proteins from trophozoite stage iRBC ghosts from A4, C24 and ltG. At 20 hours after invasion, parasites were metabolic labelled with $50 \mu \mathrm{Ci} / \mathrm{ml}$ [35S] methionine for 4 hours. IRBC ghosts were separated from the free parasite fraction and run on $\mathrm{pH}$ 4-7 IEF strips followed by $12.5 \%$ SDS-PAGE. Gels were stained with Coomassie Blue, dried and exposed to $x$-ray film. Marked circles show proteins with at least three fold changes in expression compared with C24. High quality tif files showing the original 2D gels are available for A4 (Additional file 8), C24 (Additional file 9) and ItG (Additional file I0) iRBC ghosts from trophozoite stages.
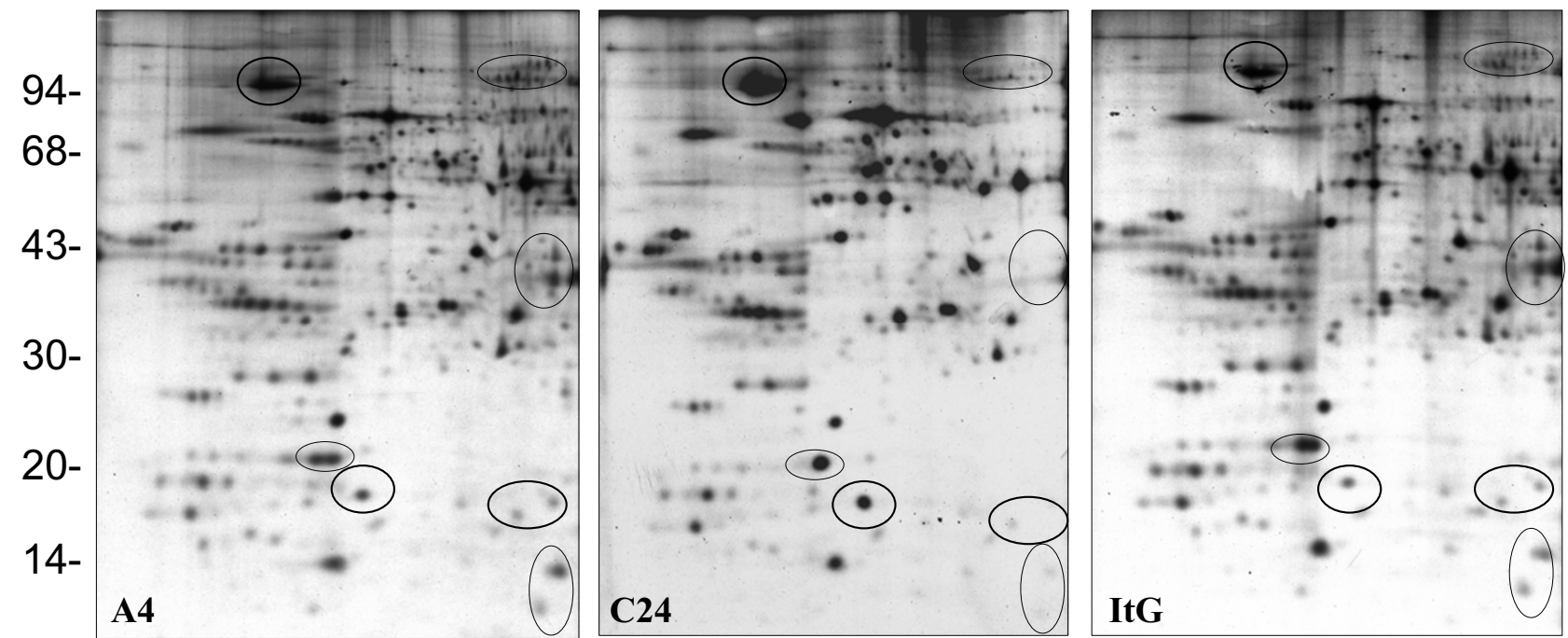

\section{Figure 4}

Autoradiograph of proteins from ring stage, free parasite fractions of A4, C24 and ItG. I0 hours after invasion and metabolic labelling, free parasites were separated from IRBC ghosts and run on $\mathrm{pH}$ 4-7 IEF strips followed by I2.5\% SDS-PAGE. Marked circles show proteins with at least three fold changes in expression compared with C24. High quality tif files showing the original 2D gels are available for A4 (Additional file II), C24 (Additional file 12) and ItG (Additional file I3) free parasites from ring stages. 

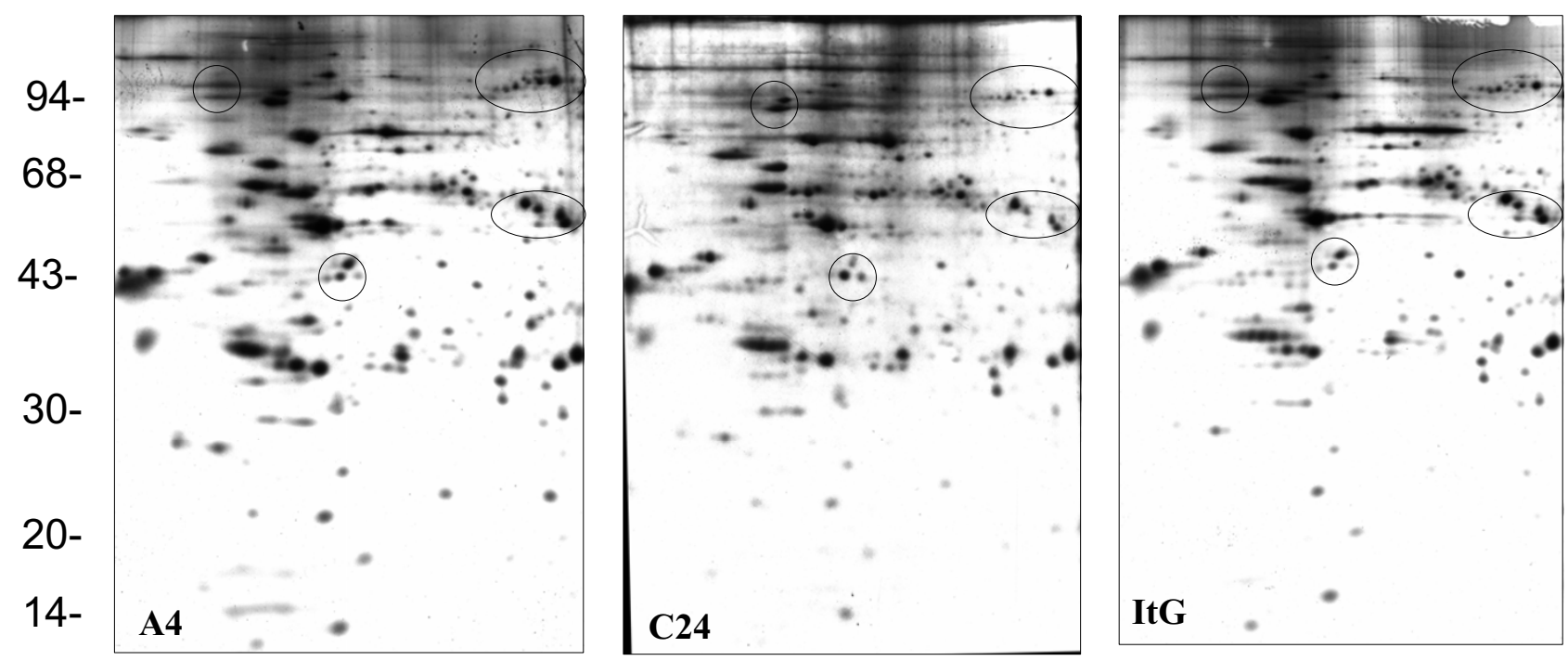

\section{Figure 5}

Autoradiograph of proteins from trophozoite stage free parasite fractions of A4, C24 and ItG. 24 hours after invasion and metabolic labelling, free parasites were separated from IRBC ghosts and run on pH 4-7 IEF strips followed by I2.5\% SDS-PAGE. Marked circles show proteins with at least three fold changes in expression compared with C24. High quality tif files showing the original 2D gels are available for A4 (Additional file 14), C24 (Additional file I5) and ItG (Additional file 16) free parasites from trophozoite stages.

iRBC, which also showed differences (data not shown). These changes were not seen on autoradiographs of the free-parasite fraction, suggesting that they could be membrane-associated events.

Autoradiography does not only describe the changes in parasite proteins but also can be used as an indicator to excise proteins for identification. As seen in Figure 7, radio-labelled iRBC samples showed over 100 proteins of parasite origin in the iRBC membrane fraction. When this type of gel is stained with Coomassie Blue, the most abundant proteins identified by MALDI-TOF were from human source. Therefore, the positions of spots on the autoradiograph were used to trace parasite proteins. Since [35S] methionine is a low energy isotope, the X-ray film needs to be in direct contact with the $2 \mathrm{D}$ gels, so the gel has to be dried, necessitating protein identification on dry spots. Despite these technical difficulties, identified a number of parasite proteins were identified (Table 1). However, there remain difficulties in identifying all the proteins, particularly low abundant ones. Indeed a number of wellcharacterized parasite proteins known to be involved in membrane association or surface localization (e.g. PfEMP1) could not be seen from the 2D map, most likely because of low abundance and hydrophobic nature, set- ting them out of the range of the protein purification and separation methodologies used here.

Parasite proteins only account for a small amount of total infected erythrocyte proteins, with over $70 \%$ of the protein spots identified as human proteins (data not shown). To further extract parasite proteins for identification, parasites were synchronized by Plasmagel flottation to enrich trophozoite stage parasites up to $80 \%$, treated infected erythrocytes with saponin for less than $7 \mathrm{~min}$ and then washed the free-parasite fraction extensively. The brief saponin treatment produces large pieces of erythrocyte membrane and free parasite, repeated washing with ice cold saline solution removes most of the contaminating host erythrocyte lysate and, therefore, enriches for parasite proteins. This sample was separated by 2D gel electrophoresis (Figure 8) and using MALDI-TOF, 58 proteins were identified from this gel, of which 28 came from parasite source.

A number of techniques can be used to increase the rate of protein identification and try to find the surface protein specifically. For example, Multidimensional Protein Identification Technology (MudPIT), a two-dimensional liquid chromatograph coupled with tandem mass spectrometry [39]; molecules exposed on the iRBC surface 
A
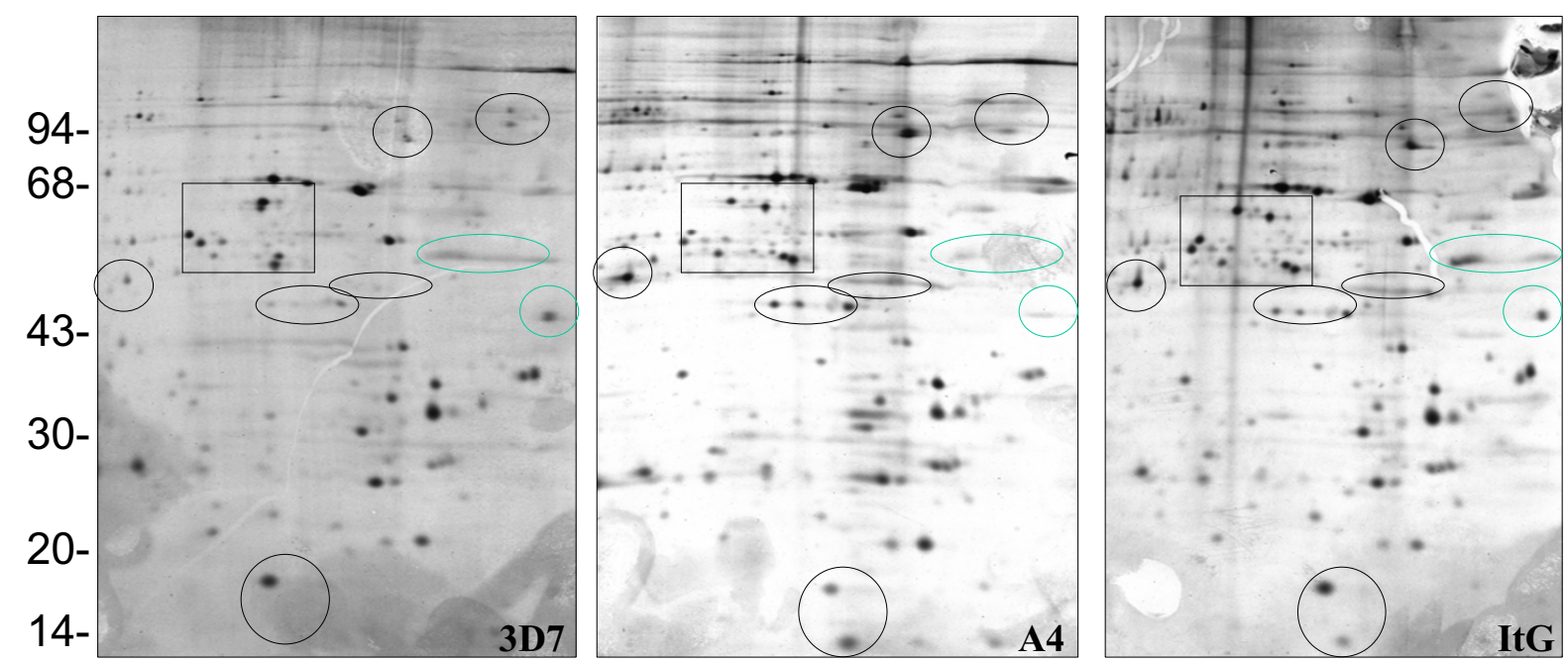

\section{B}
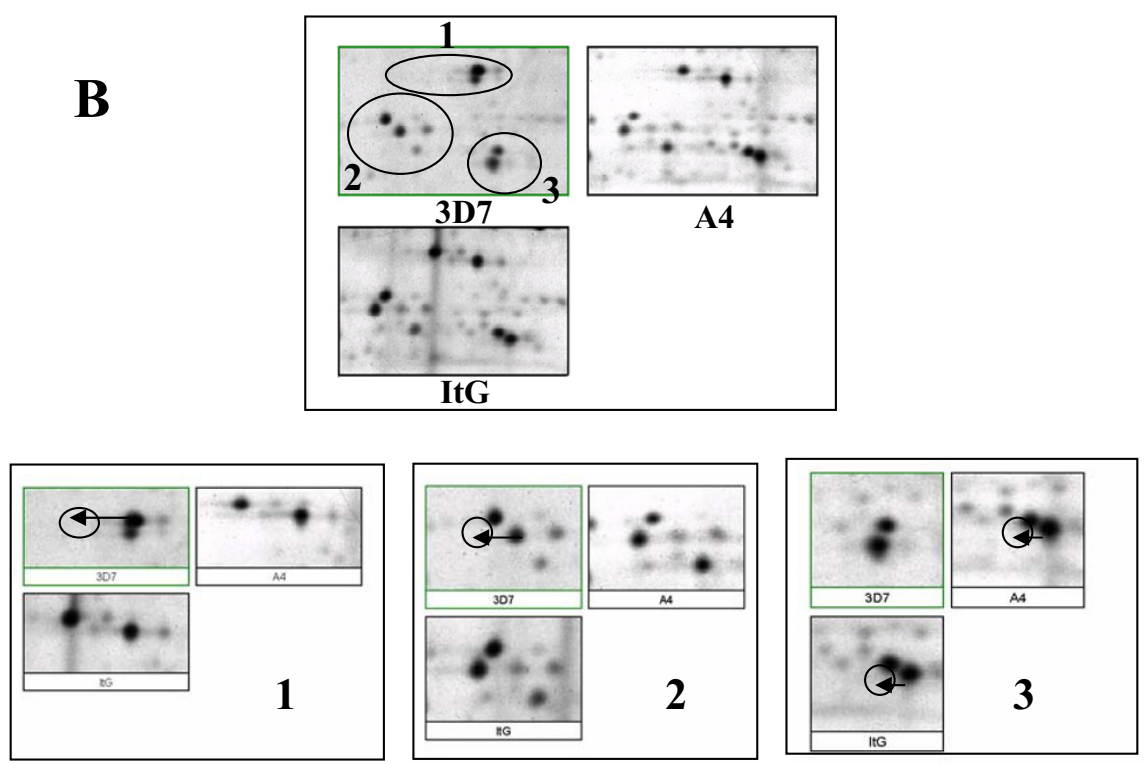

Figure 6

(A). Autoradiograph of proteins from trophozoite stage iRBC infected with 3D7, A4 and ItG. At 20 hours after invasion, parasites were metabolic labelled with $50 \mu \mathrm{Ci} / \mathrm{ml}\left[{ }^{35} \mathrm{~S}\right]$ methionine for 4 hours. iRBC ghosts were separated from the free parasite fraction and run on $\mathrm{pH}$ 4-7 IEF strips followed by I2\% SDS-PAGE. Gels were stained with Coomassie Blue, dried and exposed to $x$-ray film. Marked circles show proteins with at least three fold changes in expression compared with 3D7. High quality tif files showing the original 2D gels of metabolic labelled iRBC ghosts from parasite lines 3D7 (Additional file 17), A4 (Additional file 18) and ItG (Additional file 19) available. (B). Enlarged images of parts of Fig.6A showing significant changes in the protein profiles. Arrows and circles indicate the relative positions of the spots in different lines.

can be digested by enzyme treatment such as trypsin or chymotrypsin [40,41]; insertion molecules can be purified from membrane fractions [42]. Yimin Wu's group used biotin-streptavidin labeling to purify all proteins on the iRBC surface and identified proteins by shotgun proteomic analysis [43]. Such techniques certainly provide high throughput scale and improve the identification sensitivity. However, a problem still remained as some cytosol proteins were also present in the pool of surface proteins because of internal biotin labelling and high abundant protein non-specifically binding to streptavidin. Recently, Lingelbach's group has used furosemide, a non-specific anion transport inhibitor, to block parasiteinduced biotin permeability, making biotin-streptavidin technique more specific [44]. Another way to trace protein trafficking or protein remodelling or protein targeting is 


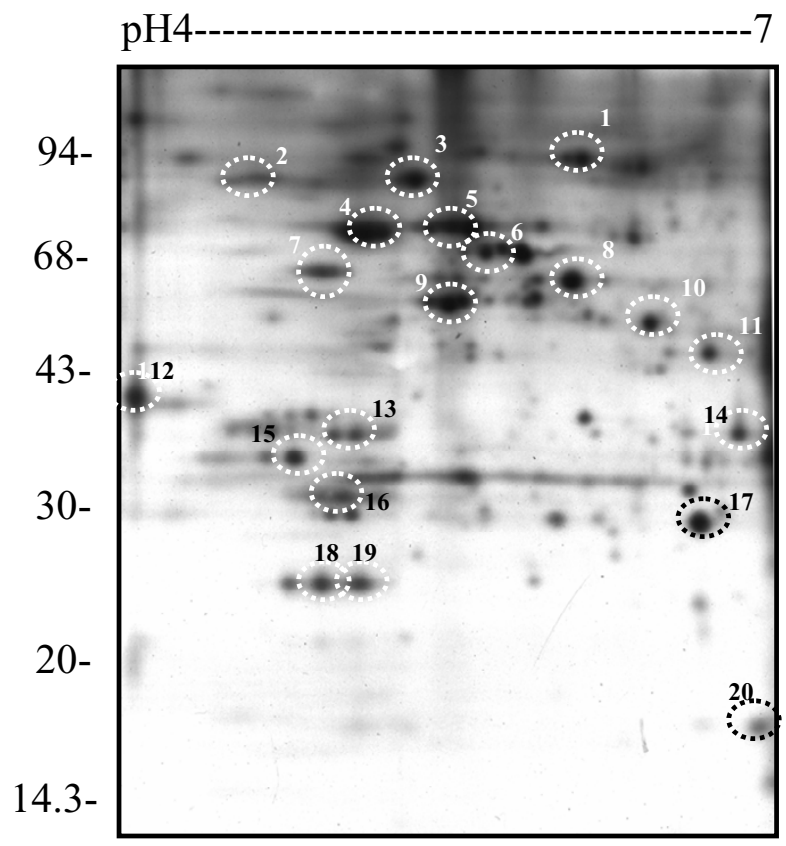

Figure 7

Identification of parasite proteins from A4 iRBC ghost fraction. The parasite proteins were traced by autoradiography, spots were excised and identified by MALDI-TOF. All marked protein IDs achieved statistically significant protein scores in the Mascot search results. An unannotated high quality psd file of the original gel is available (Additional file 20).

Table I: Protein identifications (see Fig. 7)

\begin{tabular}{|c|c|c|c|c|c|c|c|}
\hline Number & Protein ID & $\begin{array}{l}\text { Accession } \\
\text { No. }\end{array}$ & $M(\mathrm{KDa})$ & $\mathrm{PI}$ & $\begin{array}{l}\text { No. of peptides } \\
\text { matched }\end{array}$ & $\begin{array}{l}\text { \% of SQ } \\
\text { rec }\end{array}$ & $\begin{array}{l}\text { Mass } \\
\text { score }\end{array}$ \\
\hline I & Putative HSP90 & Gi 23508379 & 109.195 & 6.22 & 22 & 26 & 74 \\
\hline 2 & Glycophorin-binding protein 130 precursor & $\mathrm{Gi} 121507$ & 90.077 & 5.02 & 14 & 35 & 99 \\
\hline 3 & HSP86 & Gi236I2467 & 86.512 & 4.95 & 10 & 25 & 87 \\
\hline 4 & $78 \mathrm{KD}$ glucose regulated protein & Gi II70013 & 72.845 & 5.38 & 21 & 35 & 89 \\
\hline 5 & $78 \mathrm{KD}$ glucose regulated protein & Gi 1170013 & 72.845 & 5.38 & 21 & 35 & 89 \\
\hline 6 & PFhsp70-3 & Gi III27605 & 71.945 & 5.30 & 7 & 13 & 81 \\
\hline 7 & Hypothetical protein & Gi 23613336 & 60720 & 4.95 & 14 & 21 & 48 \\
\hline 8 & HSP60 & Gi 23507957 & 62.911 & 6.75 & 14 & 23 & 59 \\
\hline 9 & Protein disulfide isomerase & Gi III25364 & 55.782 & 5.57 & 8 & 26 & 78 \\
\hline 10 & Enolase & Gi 3023709 & 49.015 & 6.21 & 10 & 29 & 91 \\
\hline 11 & EF-Ialpha & Gi 9887 & 49.238 & 9.27 & 12 & 32 & 72 \\
\hline 12 & Endoplasmic reticulum-resident calcium binding protein & Gi 23508293 & 39.464 & 4.0 & 18 & 45 & 143 \\
\hline 13 & Variant surface antigen rifin & Gi 23505091 & 40.869 & 8.72 & 11 & 30 & 84 \\
\hline 14 & RESA-like proteinTruncated & Gi 23510225 & 36.224 & 6.7 & 6 & 21 & $43+p s d$ \\
\hline 15 & Phosphoethanolamine $\mathrm{N}$-methyltransferase & Gi 23619361 & 31.309 & 5.43 & 11 & 38 & 74 \\
\hline 16 & Falcipain & Gi76257570 & 27.623 & 4.96 & 8 & 45 & 61 \\
\hline 17 & Uridine phosphorylase & Gi 23613155 & 27.525 & 6.27 & 11 & 52 & $|4|$ \\
\hline 18 & Hypothetical protein & Gi 23613776 & 24.911 & 5.49 & 11 & 36 & 84 \\
\hline 19 & Hypothetical protein & Gi 23613776 & 24.911 & 5.49 & 11 & 36 & 84 \\
\hline 20 & Peptidyl-prolyl cis-trans isomerase & Gi 23508355 & 21.831 & 7.10 & 7 & 30 & $57+$ psd \\
\hline
\end{tabular}

by in silico prediction of host-targeting signals required for the export of proteins from the parasite vacuole to the erythrocyte membrane $[22,23]$.

The predominant modification seen on 2D gels was horizontal position changes rather than presence or absence of a protein, indicating protein post-translational modification such as phosphorylation, which increases the negative charge of the protein and shifts the iso-electric point (PI) to the more acidic side. In yeast, protein phosphorylation is estimated to affect $30 \%$ of the proteome. Using proteome chip technology, scientists have determined the in vitro substrates recognized by yeast protein kinases. 4,192 phosphorylation events involving 1,325 different proteins were identified and kinase-substrate relationships distinguished [45]. The results suggest that host and parasite proteins may experience phosphorylation changes during parasite development inside the erythrocytes.

\section{Conclusion}

Using a sensitive in vivo labelling technique allied to $2 \mathrm{D}$ electrophoresis, highly reproducible, limited changes in $P$. falciparum protein profiles from a number of parasite lines have been shown, differing in their adhesive phenotypes, with even fewer differences seen in antigenically distinct clones sharing the ability to bind to ICAM-1. Of the changes detected, most were alterations in PI, indicative of differential phosphorylation. Only a subset of the protein spots could be identified using mass spectrometry. Other studies have used non-gel methodologies, such as nano$\mathrm{LC} / \mathrm{MS} / \mathrm{MS}$ to overcome this problem, but these also have 


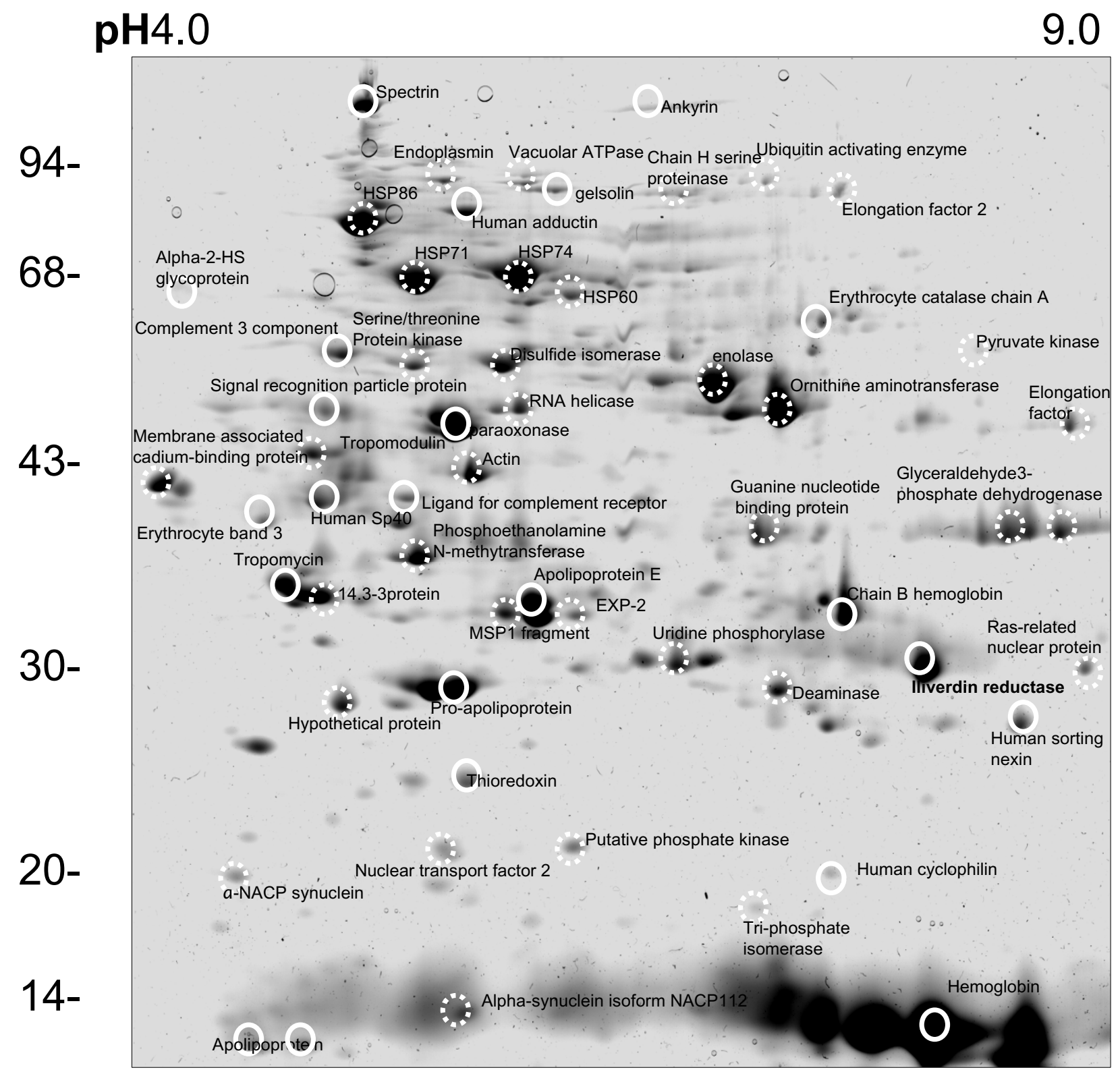

\section{Figure 8}

Representative 2D gel of parasite proteins from ItG trophozoites. ItG trophozoites were enriched 24 hours after invasion by Plasmagel floatation, the free parasite fraction was run on $\mathrm{pH} 3-10$ IEF strips followed by $12.5 \%$ SDS-PAGE and the gel was stained with Coomassie Blue. Spots were excised and identified by MALDI-TOF. Solid circles indicate proteins from human source and dotted circles label proteins from parasite source. All marked protein IDs achieved significant protein scores in Mascot search results. An unannotated high quality tif file of the original gel is available (Additional file $2 \mathrm{I}$ ).

limitations for low abundance, membrane proteins and several proteins known to be at the surface of the infected erythrocyte were not identified by this approach. Further development of biochemical techniques, detection sys- tems and sequence databases, particularly for variant surface antigen families, will be required to identify the full complement of parasite proteins in the infected erythrocyte membrane. 


\section{Authors' contributions}

Both authors participated in the design of the study. YW carried out all the experimental work. AC conceived of the study, participated in its coordination and helped to draft the manuscript. Both authors read and approved the final manuscript

\section{Additional material}

\section{Additional file 1}

$2 D$ electrophoresis profile of $i R B C$ ghosts from $3 D 7$ stained with Coomassie Blue (see figure 1).

Click here for file

[http://www.biomedcentral.com/content/supplementary/14752875-5-67-S1.tiff]

\section{Additional file 2}

$2 D$ electrophoresis profile of $i R B C$ ghosts from $3 D 7$ stained with silver (see figure 1).

Click here for file

[http://www.biomedcentral.com/content/supplementary/14752875-5-67-S2.tiff]

\section{Additional file 3}

$2 D$ electrophoresis profile of $i R B C$ ghosts from A4 stained with Coomassie Blue (see figure 1).

Click here for file

[http://www.biomedcentral.com/content/supplementary/1475-

2875-5-67-S3.tiff]

\section{Additional file 4}

$2 D$ electrophoresis profile of $i R B C$ ghosts from A4 stained with silver (see figure 1).

Click here for file

[http://www.biomedcentral.com/content/supplementary/14752875-5-67-S4.tiff]

\section{Additional file 5}

Autoradiograph of 2D electrophoresis profile of metabolically labelled proteins from ring stage iRBC ghosts from A4 (see figure 2).

Click here for file

[http://www.biomedcentral.com/content/supplementary/14752875-5-67-S5.tiff]

\section{Additional file 6}

Autoradiograph of $2 \mathrm{D}$ electrophoresis profile of metabolically labelled proteins from ring stage iRBC ghosts from C24 (see figure 2).

Click here for file

[http://www.biomedcentral.com/content/supplementary/1475-

2875-5-67-S6.tiff]

\section{Additional file 7}

Autoradiograph of 2D electrophoresis profile of metabolically labelled proteins from ring stage iRBC ghosts from ItG (see figure 2).

Click here for file

[http://www.biomedcentral.com/content/supplementary/14752875-5-67-S7.tiff]

\section{Additional file 8}

Autoradiograph of $2 D$ electrophoresis profile of metabolically labelled proteins from trophozoite stage iRBC ghosts from A4 (see figure 3).

Click here for file

[http://www.biomedcentral.com/content/supplementary/14752875-5-67-S8.tiff]

\section{Additional file 9}

Autoradiograph of $2 D$ electrophoresis profile of metabolically labelled proteins from trophozoite stage iRBC ghosts from C24 (see figure 3).

Click here for file

[http://www.biomedcentral.com/content/supplementary/1475-

2875-5-67-S9.tiff]

\section{Additional file 10}

Autoradiograph of $2 D$ electrophoresis profile of metabolically labelled proteins from trophozoite stage iRBC ghosts from ItG (see figure 3 ).

Click here for file

[http://www.biomedcentral.com/content/supplementary/1475-

2875-5-67-S10.tiff]

\section{Additional file 11}

Autoradiograph of $2 \mathrm{D}$ electrophoresis profile of metabolically labelled proteins from ring stage free parasites from A4 (see figure 4).

Click here for file

[http://www.biomedcentral.com/content/supplementary/14752875-5-67-S11.tiff]

\section{Additional file 12}

Autoradiograph of $2 D$ electrophoresis profile of metabolically labelled proteins from ring stage free parasites from C24 (see figure 4).

Click here for file

[http://www.biomedcentral.com/content/supplementary/1475-

2875-5-67-S12.tiff]

\section{Additional file 13}

Autoradiograph of $2 \mathrm{D}$ electrophoresis profile of metabolically labelled proteins from ring stage free parasites from ItG (see figure 4).

Click here for file

[http://www.biomedcentral.com/content/supplementary/1475-

2875-5-67-S13.tiff]

\section{Additional file 14}

Autoradiograph of $2 \mathrm{D}$ electrophoresis profile of metabolically labelled proteins from trophozoite stage free parasites from A4 (see figure 5).

Click here for file

[http://www.biomedcentral.com/content/supplementary/14752875-5-67-S14.tiff]

\section{Additional file 15}

Autoradiograph of $2 D$ electrophoresis profile of metabolically labelled proteins from trophozoite stage free parasites from C24 (see figure 5).

Click here for file

[http://www.biomedcentral.com/content/supplementary/1475-

2875-5-67-S15.tiff] 


\section{Additional file $\mathbf{1 6}$ \\ Autoradiograph of 2D electrophoresis profile of metabolically labelled pro- teins from trophozoite stage free parasites from ItG (see figure 5). \\ Click here for file \\ [http://www.biomedcentral.com/content/supplementary/1475- 2875-5-67-S16.tiff]}

\section{Additional file 17}

Autoradiograph of $2 \mathrm{D}$ electrophoresis profile of metabolically labelled proteins from $i R B C$ ghosts from $3 D 7$ (see figure 6).

Click here for file

[http://www.biomedcentral.com/content/supplementary/1475-

2875-5-67-S17.tiff]

\section{Additional file 18}

Autoradiograph of 2D electrophoresis profile of metabolically labelled proteins from iRBC ghosts from A4 (see figure 6).

Click here for file

[http://www.biomedcentral.com/content/supplementary/14752875-5-67-S18.tiff]

\section{Additional file 19}

Autoradiograph of $2 \mathrm{D}$ electrophoresis profile of metabolically labelled proteins from $i R B C$ ghosts from ItG (see figure 6).

Click here for file

[http://www.biomedcentral.com/content/supplementary/14752875-5-67-S19.tiff]

\section{Additional file 20}

Preparative $2 D$ gel for protein identification of $A 4 i R B C$ ghost fraction (see figure 7 and table 1).

Click here for file

[http://www.biomedcentral.com/content/supplementary/1475-

2875-5-67-S20.psd]

\section{Additional file 21}

Unannotated $2 D$ electrophoresis profile from It $G$ trophozoite, free parasite fraction (see figure 8 ).

Click here for file

[http://www.biomedcentral.com/content/supplementary/14752875-5-67-S21.tiff]

\section{Acknowledgements}

We would like to thank Prof. John Hyde and Drs. Paul Sims and Niroshini Nirmalan (University of Manchester) for their help in establishing 2D electrophoresis in our laboratory, Ms. Evelyn Gitau for her help with mass spectrometry and Prof. Steve Ward and Dr Rob Harrison for discussions and critical reading of the manuscript. This work was funded by the Wellcome Trust (Functional Genomics Initiative).

\section{References}

I. Barnwell JW, Asch AS, Nachman RL, Yamaya M, Aikawa M, Ingravallo $P$ : A human 88-kD membrane glycoprotein (CD36) functions in vitro as a receptor for a cytoadherence ligand on Plasmodium falciparum-infected erythrocytes. J Clin Invest 1989, 84(3):765-772.

2. Oquendo $P$, Hundt E, Lawler J, Seed B: CD36 directly mediates cytoadherence of Plasmodium falciparum parasitized erythrocytes. Cell 1989, 58(1):95-I0I.

3. Ockenhouse CF, Tandon NN, Magowan C, Jamieson GA, Chulay JD: Identification of a platelet membrane glycoprotein as a falci- parum malaria sequestration receptor [see comments]. Science 1989, 243(4897): |469-|47|.

4. Berendt AR, Simmons DL, Tansey J, Newbold Cl, Marsh K: Intercellular adhesion molecule-I is an endothelial cell adhesion receptor for Plasmodium falciparum. Nature 1989, 34I(6237):57-59.

5. Roberts DD, Sherwood JA, Spitalnik SL, Panton LJ, Howard RJ, Dixit VM, Frazier WA, Miller LH, Ginsburg V: Thrombospondin binds falciparum malaria parasitized erythrocytes and may mediate cytoadherence. Nature 1985, 3 I 8(604I):64-66.

6. Ockenhouse CF, Tegoshi T, Maeno Y, Benjamin C, Ho M, Kan KE, Thway Y, Win K, Aikawa M, Lobb RR: Human vascular endothelial cell adhesion receptors for Plasmodium falciparuminfected erythrocytes: roles for endothelial leukocyte adhesion molecule I and vascular cell adhesion molecule I. J Exp Med 1992, I76(4): I 183-II89.

7. Udomsangpetch R, Reinhardt PH, Schollaardt $T$, Elliott JF, Kubes $P$, Ho M: Promiscuity of clinical Plasmodium falciparum isolates for multiple adhesion molecules under flow conditions. J Immunol 1997, I 58(9):4358-4364.

8. Siano JP, Grady KK, Millet P, Wick TM: Short report: Plasmodium falciparum: cytoadherence to alpha(v)beta3 on human microvascular endothelial cells. Am J Trop Med Hyg 1998, 59(I):77-79.

9. Treutiger CJ, Heddini A, Fernandez V, Muller WA, Wahlgren M: PECAM-I/CD3I, an endothelial receptor for binding Plasmodium falciparum- infected erythrocytes [see comments]. Nat Med 1997, 3( I 2): 1405-1408.

10. Rogerson SJ, Chaiyaroj SC, Ng K, Reeder JC, Brown GV: Chondroitin sulfate $A$ is a cell surface receptor for Plasmodium falciparum-infected erythrocytes. J Exp Med 1995, I 82(I): 15-20

II. Rowe JA, Moulds JM, Newbold Cl, Miller LH: P. falciparum rosetting mediated by a parasite-variant erythrocyte membrane protein and complement-receptor I. Nature 1997, 388(6639):292-295.

12. Vogt AM, Winter G, Wahlgren M, Spillmann D: Heparan sulphate identified on human erythrocytes: a Plasmodium falciparum receptor. Biochem J 2004, 38I (Pt 3):593-597.

13. Chen Q, Heddini A, Barragan A, Fernandez V, Pearce SF, Wahlgren $M$ : The semiconserved head structure of Plasmodium falciparum erythrocyte membrane protein I mediates binding to multiple independent host receptors. J Exp Med 2000, 192(I): $1-10$

14. Roberts DJ, Pain A, Kai O, Kortok M, Marsh K: Autoagglutination of malaria-infected red blood cells and malaria severity [letter]. Lancet 2000, 355(92/3): 1427-1428.

15. Baruch DI, Pasloske BL, Singh HB, Bi X, Ma XC, Feldman M, Taraschi TF, Howard RJ: Cloning the P. falciparum gene encoding PfEMPI, a malarial variant antigen and adherence receptor on the surface of parasitized human erythrocytes [see comments]. Cell 1995, 82(I):77-87.

16. Su XZ, Heatwole VM, Wertheimer SP, Guinet F, Herrfeldt JA, Peterson DS, Ravetch JA, Wellems TE: The large diverse gene family var encodes proteins involved in cytoadherence and antigenic variation of Plasmodium falciparum-infected erythrocytes [see comments]. Cell 1995, 82(I):89-100.

17. Smith JD, Chitnis CE, Craig AG, Roberts DJ, Hudson-Taylor DE, Peterson DS, Pinches R, Newbold Cl, Miller LH: Switches in expression of Plasmodium falciparum var genes correlate with changes in antigenic and cytoadherent phenotypes of infected erythrocytes [see comments]. Cell 1995, 82(I): $|0|-|| \mid 0$.

18. Gardner MJ, Hall N, Fung E, White O, Berriman M, Hyman RW, Carlton JM, Pain A, Nelson KE, Bowman S, Paulsen IT, James K, Eisen JA, Rutherford K, Salzberg SL, Craig A, Kyes S, Chan MS, Nene V, Shallom SJ, Suh B, Peterson J, Angiuoli S, Pertea M, Allen J, Selengut J, Haft $D$, Mather MW, Vaidya AB, Martin DM, Fairlamb AH, Fraunholz MJ, Roos DS, Ralph SA, McFadden GI, Cummings LM, Subramanian GM, Mungall C, Venter JC, Carucci DJ, Hoffman SL, Newbold C, Davis RW, Fraser CM, Barrell B: Genome sequence of the human malaria parasite Plasmodium falciparum. Nature 2002, 4| 9(6906):498-5I|.

19. Fried M, Duffy PE: Adherence of Plasmodium falciparum to chondroitin sulfate $A$ in the human placenta [see comments]. Science 1996, 272(5267):1502-1504. 
20. Craig A, Scherf A: Molecules on the surface of the Plasmodium falciparum infected erythrocyte and their role in malaria pathogenesis and immune evasion. Mol Biochem Parasitol 200I, I I 5(2): | 29-143.

21. Winter G, Kawai S, Haeggstrom M, Kaneko O, von Euler A, Kawazu $S$, Palm D, Fernandez $V$, Wahlgren M: SURFIN is a polymorphic antigen expressed on Plasmodium falciparum merozoites and infected erythrocytes. J Exp Med 2005, 20 I (I I): I853-I863.

22. Hiller NL, Bhattacharjee S, van Ooij C, Liolios K, Harrison T, LopezEstrano C, Haldar K: A host-targeting signal in virulence proteins reveals a secretome in malarial infection. Science 2004, 306(5703): 1934-1937.

23. Marti M, Good RT, Rug M, Knuepfer E, Cowman AF: Targeting malaria virulence and remodeling proteins to the host erythrocyte. Science 2004, 306(5703): 1930-1933.

24. Sargeant TJ, Marti M, Caler E, Carlton JM, Simpson K, Speed TP, Cowman AF: Lineage-specific expansion of proteins exported to erythrocytes in malaria parasites. Genome Biol 2006, 7(2):RI2.

25. Roberts DJ, Craig AG, Berendt AR, Pinches R, Nash G, Marsh K, Newbold $\mathrm{Cl}$ : Rapid switching to multiple antigenic and adhesive phenotypes in malaria [see comments]. Nature 1992 357(6380):689-692.

26. Biggs BA, Anders RF, Dillon HE, Davern KM, Martin M, Petersen C Brown GV: Adherence of infected erythrocytes to venular endothelium selects for antigenic variants of Plasmodium falciparum. I Immunol 1992, I 49(6):2047-2054.

27. Ockenhouse CF, Ho M, Tandon NN, Van Seventer GA, Shaw S, White NJ, Jamieson GA, Chulay JD, Webster HK: Molecular basis of sequestration in severe and uncomplicated Plasmodium falciparum malaria: differential adhesion of infected erythrocytes to CD36 and ICAM-I. J Infect Dis I99I, I64(I):I63-I69.

28. Gray C, McCormick C, Turner G, Craig A: ICAM-I can play a major role in mediating $P$. falciparum adhesion to endothelium under flow. Mol Biochem Parasitol 2003, I 28(2): | 87-193.

29. Tse MT, Chakrabarti K, Gray C, Chitnis CE, Craig A: Divergent binding sites on intercellular adhesion molecule-I (ICAM-I) for variant Plasmodium falciparum isolates. Mol Microbiol 2004, 5 I (4): I039-1049.

30. Delemarre B], van der Kaay H]: [Tropical malaria contracted the natural way in the Netherlands]. Ned Tijdschr Geneeskd 1979 I 23(46): 1981-1982.

31. Walliker D, Quakyi IA, Wellems TE, McCutchan TF, Szarfman A, London WT, Corcoran LM, Burkot TR, Carter R: Genetic analysis of the human malaria parasite Plasmodium falciparum. Science |987, 236(4809): |66|-|666.

32. Trager W, Jensen JB: Human malaria parasites in continuous culture. Science 1976, 193(4254):673-675.

33. Laemmli UK: Cleavage of structural proteins during the assembly of the head of bacteriophage T4. Nature 1970, 227(5259):680-685

34. Nirmalan N, Sims PF, Hyde JE: Quantitative proteomics of the human malaria parasite Plasmodium falciparum and its application to studies of development and inhibition. Mol Microbiol 2004, 52(4): I I87- I I 99.

35. MASCOT Peptide Mass Fingerprinting program MS: http:// www.matrixscience.com.

36. Magowan C, Nunomura W, Waller KL, Yeung J, Liang J, Van Dort H, Low PS, Coppel RL, Mohandas N: Plasmodium falciparum histidine-rich protein I associates with the band 3 binding domain of ankyrin in the infected red cell membrane. Biochim Biophys Acta 2000, I 502(3):46 1-470.

37. Pei X, An X, Guo X, Tarnawski M, Coppel R, Mohandas N: Structural and functional studies of interaction between Plasmodium falciparum knob-associated histidine-rich protein (KAHRP) and erythrocyte spectrin. I Biol Chem 2005, 280(35):3।|66-3 II7I.

38. Paulitschke $M$, Nash GB: Membrane rigidity of red blood cells parasitized by different strains of Plasmodium falciparum. J Lab Clin Med 1993, I 22(5):58I-589.

39. Washburn MP, Yates JR: Analysis of the microbial proteome. Curr Opin Microbiol 2000, 3(3):292-297.

40. Puentes A, Ocampo M, Rodriguez LE, Vera R, Valbuena J, Curtidor H, Garcia J, Lopez R, Tovar D, Cortes ], Rivera Z, Patarroyo ME: Identifying Plasmodium falciparum merozoite surface protein- 10 human erythrocyte specific binding regions. Biochimie 2005, 87(5):46I-472.
41. Curtidor H, Urquiza M, Suarez JE, Rodriguez LE, Ocampo M, Puentes A, Garcia JE, Vera R, Lopez R, Ramirez LE, Pinzon M, Patarroyo ME: Plasmodium falciparum acid basic repeat antigen (ABRA) peptides: erythrocyte binding and biological activity. Vaccine 200 I, I 9(3 I):4496-4504.

42. Low TY, Seow TK, Chung MC: Separation of human erythrocyte membrane associated proteins with one-dimensional and two-dimensional gel electrophoresis followed by identification with matrix-assisted laser desorption/ionization-time of flight mass spectrometry. Proteomics 2002, 2(9): I229- I 239.

43. Florens L, Liu X, Wang Y, Yang S, Schwartz O, Peglar M, Carucci DJ, Yates JR, Wu Y: Proteomics approach reveals novel proteins on the surface of malaria-infected erythrocytes. Mol Biochem Parasitol 2004, I 35(I): I- I I.

44. Baumeister S, Endermann T, Charpian S, Nyalwidhe J, Duranton C, Huber S, Kirk K, Lang F, Lingelbach K: A biotin derivative blocks parasite induced novel permeation pathways in Plasmodium falciparum-infected erythrocytes. Mol Biochem Parasitol 2003, I 32(I):35-45

45. Ptacek J, Devgan G, Michaud G, Zhu H, Zhu X, Fasolo J, Guo H, Jona G, Breitkreutz A, Sopko R, McCartney RR, Schmidt MC, Rachidi N, Lee SJ, Mah AS, Meng L, Stark MJ, Stern DF, De Virgilio C, Tyers M, Andrews B, Gerstein M, Schweitzer B, Predki PF, Snyder M: Global analysis of protein phosphorylation in yeast. Nature 2005 , 438(7068):679-684.

Publish with Bio Med Central and every scientist can read your work free of charge

"BioMed Central will be the most significant development for disseminating the results of biomedical research in our lifetime. "

Sir Paul Nurse, Cancer Research UK

Your research papers will be:

- available free of charge to the entire biomedical community

- peer reviewed and published immediately upon acceptance

- cited in PubMed and archived on PubMed Central

- yours - you keep the copyright
BioMedcentral 